Jonathan Valk*

\title{
The Origins of the Assyrian King List
}

https://doi.org/10.1515/janeh-2017-0009

\begin{abstract}
The Assyrian King List (AKL) is central to the reconstruction of Assyrian and broader Near Eastern history and chronology. Because of AKL's significance, locating its original moment of composition has far-reaching historiographical implications. There is no scholarly consensus on the dating of AKL, but a closer look at the internal evidence of AKL indicates a firm, fifteenth century terminus post quem for the creation of AKL, while the bilingual tablet fragment BM 98496 establishes the thirteenth century reign of Tukulti-Ninurta I as a secure terminus ante quem. Within this temporal range, it is possible to trace the genesis of AKL to the reign of Aššur-uballit I. This period witnessed great change in Assyria, and the nature of this change provides an ideal historical, political, and ideological context for the production of AKL. No other moment in Assyrian history offers so compelling a conjunction of political motives and historical circumstances for AKL's composition.
\end{abstract}

Keywords: Assyria, king list, Assyrian king list, Aššur-uballiṭ, Middle Assyrian

\section{Introduction}

It would be a stretch to suggest that king lists are, on the face of it, among the more stimulating of ancient Near Eastern texts. The name of the genre - king lists - well describes their contents: a series of kings, one following the other, for generation after generation. The Assyrian King List - AKL for short - is no different in this respect, comprising as it does in its latest iteration a sequence of 109 individual entries spanning a chronological period well in excess of a millennium. ${ }^{1}$ But AKL is more than a straightforward agglomeration of kings:

Correction note: Correction added after ahead-of-print publication on August 17, 2018: The author's affiliation inadvertently listed USA in the country. This has now been removed to reflect the correct country.

1 For an edition of the Assyrian King List with relevant bibliography, see Grayson (1980-83). I adopt Grayson's numbering for AKL's entries. Following Yamada (1994: 11, fn. 1), Arabic numerals are preferred to the Roman numerals used by Grayson.

*Corresponding author: Jonathan Valk, Leiden Institute for Area Studies, Universiteit Leiden, Leiden, the Netherlands, E-mail: j.valk@hum.leidenuniv.nl 
the information that it conveys and the manner in which this data is communicated advance a particular narrative. Beyond AKL's central importance to the reconstruction of ancient Near Eastern and particularly Assyrian history and chronology, the text is interesting precisely because it tells a story. It is in identifying this story and situating it historically, moreover, that we can best hope to make sense of AKL's origins. ${ }^{2}$ What this approach yields is the conclusion that AKL in the form that it is known to us was most likely composed in fourteenth century Aššur, during the reign of Aššur-uballit I, as one element in a broad program of reform and reinvention. AKL was then updated with the passing of successive kings at least through to the second half of the eighth century BCE, and very likely through to the demise of the Assyrian state at the end of the seventh century BCE.

\section{The manuscripts}

There are five known manuscripts of AKL: the Nassouhi King List (AKL A), ${ }^{3}$ the Khorsabad King List (AKL B), the SDAS King List (AKL C), ${ }^{4}$ KAV 15 (AKL D), ${ }^{5}$ and BM 128059 (AKL E). ${ }^{6}$ Manuscripts A, B, and C are substantially preserved, while $\mathrm{D}$ and $\mathrm{E}$ are mere fragments. To the extent that they can be read, all five manuscripts attest to the transmission of an essentially fixed text. This text was added to over time to include entries for each new Assyrian king. The practice of continuous addition is apparent in the different endpoints of AKL A, B, and C. AKL A concludes with king Tiglath-Pileser II (967-935), implying that it was written shortly after his reign in the second half of the tenth century. Similarly, the conclusion of AKL B and AKL C with kings Aššur-nārārī V (755-745) and Shalmaneser V (727-722) respectively implies that both manuscripts should be dated to different points in the second half of the eighth century. In the case of AKL B, this dating is confirmed by a colophon that records that the manuscript

2 In the spirit of Mario Liverani's argument that "in order to recover the aims of the ancient authors, we have to focus our attention on the political problem which originated the text," for which see Liverani (1993: 51).

3 Nassouhi (1927). In designating this manuscript as AKL A, I adopt the sigla of Grayson (198083); I likewise adopt Grayson's sigla for the other manuscripts of AKL.

4 Both the Khorsabad King List and the SDAS King List are edited in Gelb (1954).

5 Schroeder (1920: 24).

6 Millard (1970: 174-76). 
was written in the eponymate for the year 738 - less than a decade after the death of AKL B's final entry and during the reign of that entry's successor. The fragmentary nature of AKL D and AKL E rules out precise dating of these manuscripts, but their orthographic features situate them around the tenth century. ${ }^{7}$ All five manuscripts were found in major centres of Assyrian kingship: Aššur (AKL A and D), Nineveh (AKL C and E), and Khorsabad/DūrŠarrukin (AKL B). The existing manuscripts thus attest to the transmission and use of AKL in primary loci of Assyrian royal activity between at least the tenth and eighth centuries BCE, a time when the textual tradition was frozen and altered only to reflect the succession of kings.

Despite the ongoing transmission and use of a fixed AKL text, there are differences between the manuscripts. ${ }^{8}$ The regnal lengths of six kings vary ${ }^{9}$; AKL A omits Shalmaneser II (entry 93) altogether; variant filiations are attested for three kings ${ }^{10}$; AKL A and AKL B record Tukultī-Ninurta I's successor as Aššur-nādin-apli, whereas AKL C gives his name as Aššur-nāșir-apli ${ }^{11}$; and AKL E preserves a variant name for one early entry. ${ }^{12}$ In broader perspective, these differences are minor. The process of adding new entries to AKL and the wear and tear of time required the production of new manuscripts, which were

7 There is a basic discussion of the chronology of the various AKL manuscripts in Pruzsinszky (2009: 45-47); see Millard (1970: 176) for a discussion of the dating of AKL E. Poebel (1942a: 251) argues that AKL D is the oldest of the surviving AKL manuscripts, suggesting an eleventh century date.

8 There are useful overviews of these differences in Brinkman (1973: 311-12) and Pruzsinszky (2009: 55-66).

9 These are the reigns of Erišum I (entry 33), Puzur-Aššur III (entry 61), Aššur-nādin-apli (entry 79), Ninurta-apil-Ekur (entry 82), Aššur-dān I (entry 83), and Tiglath-Pileser II (entry 97). It is also possible that there are differences in the recorded regnal lengths of Išme-Dagan I (entry 40), Tukultī-Ninurta I (entry 78), and Aššur-rabî II (entry 95), but this is unclear due to the poor state of the manuscripts at the relevant points and the consequent disagreements about how these entries should be read. Grayson (1969: 109, fn. 15), for instance, argues that both AKL B and AKL C record 40 regnal years for Išme-Dagan I, whereas Gelb (1954) and Landsberger (1954) report that AKL C disagrees with AKL B by assigning a reign of 50 years to Išme-Dagan I.

10 Erība-Adad I (entry 72), Adad- nārārī I (entry 76), and Aššur-nārārī III (entry 80).

11 For a detailed hypothesis concerning why Aššur-nādin-apli became Aššur-nāṣir-apli in AKL C, see Poebel (1942b: 484-488, and p. 481) for evidence of "an inclination, of course quite unconscious, on the part of the copying scribes to extend the usual father-son relationship between a king and his immediate successor to cases where that relationship actually did not exist." Shigeo Yamada offers his own interpretation of this problem in Yamada (1998).

12 Entry number seven. Millard (1970: 175) tentatively reads this entry as ah-hi-șu in AKL E, while AKL B and AKL C record the name Imșu. 
copied directly from previous manuscripts. In their colophons, AKL B and C tell us explicitly that they were copies. ${ }^{13}$ AKL A and D both contain the scribal insertion hepi (broken), which indicates that they were copied from manuscripts that had suffered damage and in which the relevant passages were no longer legible. ${ }^{14}$ Given that the known AKL manuscripts are copies, the differences between them can and should be attributed to copying errors. ${ }^{15}$ This conclusion is reinforced by the nature of the differences between the manuscripts. All differences in the recorded regnal lengths of kings in the AKL manuscripts, for example, amount to either one or ten years. In the cuneiform writing system, this means the mistaken omission or addition of a single wedge - plausible oversights in manuscripts that can list up to 109 individual kings. Indeed, in light of the large number of kings and regnal lengths in $\mathrm{AKL}$, the inconsistencies between the five known manuscripts are actually quite few. These inconsistencies can, moreover, be interpreted unproblematically and without exception as scribal errors - in line with the principle of Occam's razor. ${ }^{16}$

Even if some sense can be made of why there are differences between the five AKL manuscripts, this has little bearing on AKL's other problematic aspects. The first half of the text is a curious combination of disparate groups of kings, which are divided into discrete sections by editorial comments and distinct formats (see Table 1 for a visualization of AKL's sections and their

13 AKL B iv 33 states that the text is a gabarû Aššur (copy of Aššur), and AKL C iv 28 reads kima labirišsu šațir bari (written and collated according to the original).

[Correction added after ahead-of-print publication on August 17, 2018: The misprint of satir in Footnote 13 has been amended to šatiri.]

14 See Worthington (2012: 25-27) for a discussion of the meaning and use of the scribal insertion hepi.

15 For a wonderful study of how variation and error can surface in the copying and transmission of otherwise fixed Akkadian texts, see Worthington (2012). Regarding divergences in regnal years in the various AKL manuscripts, Worthington's typologies of lapsus styli (95-96) and incomplete signs (106-107) seem especially relevant, while aberratio oculi (104) is a plausible explanation for the omission of Shalmaneser II in AKL A.

16 Hagens (2005: 27-28) argues that the differences between AKL A and AKL B and C are attributable not to scribal error but to later redaction, yet he offers no compelling reason for why these minor changes would have been made by any redactor. In the absence of a compelling reason for the systematic implementation of minor changes in AKL, no such differences should be regarded as deliberate. There are also instances where AKL A agrees with one of AKL B or C against the other, further undermining Hagens' suggestion of deliberate redaction of AKL in the Neo-Assyrian period. 
Table 1: The Assyrian king list, divided by section.

\begin{tabular}{|c|c|c|c|}
\hline Kings & Description & Circa (BCE) & Format and Commentary \\
\hline \multirow[t]{2}{*}{$1-17$} & \multirow{2}{*}{$\begin{array}{l}\text { Amorite } \\
\text { Genealogy }\end{array}$} & \multirow[t]{2}{*}{$\mathrm{n} / \mathrm{a}$} & $\begin{array}{l}\text { Names only. See Finkelstein } 1966 \text { for the } \\
\text { inclusion of a parallel sequence in the } \\
\text { Genealogy of the Hammurabi Dynasty. }\end{array}$ \\
\hline & & & Duplication of Apiašal as the last and \\
\hline \multirow{3}{*}{$17-26$} & \multirow{3}{*}{$\begin{array}{l}\text { Ancestors of } \\
\text { Šamšī-Adad I }\end{array}$} & \multirow{3}{*}{$1950(?)-1800$} & first entry of the respective sections. \\
\hline & & & $\begin{array}{l}X \text { the son of } Y \text {. Reverse chronological } \\
\text { order. }\end{array}$ \\
\hline & & & \multirow{2}{*}{$\begin{array}{l}\text { Fabricated filial link between the last } \\
\text { and first entry of the respective } \\
\text { sections (Sulili as the son of Aminu). }\end{array}$} \\
\hline \multirow[t]{2}{*}{$27-32$} & \multirow{2}{*}{$\begin{array}{l}\text { Kings without } \\
\text { Eponyms }\end{array}$} & \multirow[t]{2}{*}{ 2050(?)-1972 } & \\
\hline & & & $\begin{array}{l}\text { Filiation for the first entry, names only } \\
\text { for the other five. }\end{array}$ \\
\hline $33-40$ & Standard Section & $1972-1775$ & $\begin{array}{l}X \text { the son of } Y \text { exercised kingship } \\
\text { (̌̌arrūta ïpuš) for } n \text { years. }\end{array}$ \\
\hline $41-47$ & Sons of Nobodies & 18th c. & Names only. Omission of historical kings. \\
\hline $48-72$ & Standard Section & 18th c. $-1363 / 53^{*}$ & $\begin{array}{l}\text { Terminus post quem (somewhere } \\
\text { around 1500). } \\
X \text { the son of } Y \text { exercised kingship } \\
\text { (šarrūta īpuš) for } n \text { years. }\end{array}$ \\
\hline 73 & Aššur-uballiț I & $1363 / 53-1328 / 18^{*}$ & Suggested window of composition. \\
\hline $74-77$ & Standard Section & $1328 / 18-1243 / 33^{*}$ & $\begin{array}{l}X \text { the son of } Y \text { exercised kingship } \\
\text { (šarrūta ïpuš) for } n \text { years. }\end{array}$ \\
\hline 78 & Tukultī-Ninurta I & $1243 / 33-1207 / 1197^{\star}$ & Terminus ante quem (Lambert 1976). \\
\hline $79-109$ & Standard Section & $1207 / 1197^{\star}-722$ & $\begin{array}{l}X \text { the son of } Y \text { exercised kingship } \\
\text { (̌̌arrūta ïpuš) for } n \text { years. }\end{array}$ \\
\hline
\end{tabular}

*10 year margin of uncertainty due to a disagreement in the surviving AKL manuscripts regarding the regnal length of entry \#82, Ninurta-apil-Ekur, who ruled for either 3 or 13 years: $1193 / 83-1180$.

formats). Not all sections record the filiation or regnal lengths of entries, and the second section presents its entries in reverse order. These and other irregularities have been widely noted and are best understood as a 
consequence of AKL's prehistory. ${ }^{17}$ At a certain historical moment, ${ }^{18}$ a conscious effort was undertaken to stitch together various records into a single text. It is in this initial moment of stitching together that we must look for the origins of AKL, a fixed text that then took on its subsequent life of ongoing expansion with each passing Assyrian monarch. Only by looking more closely at the story that AKL seeks to tell can we hope to identify AKL's origin.

\section{The story}

So what is AKL's story? As is implicit in the nature of king lists, AKL's story is one of continuity - of an unending sequence of kings receding deep into the mists of time. This observation is not as straightforward as it seems: there is a great deal of diversity in the king list genre, and AKL is unique in its particular combination of extraordinary chronological reach, an exclusive interest in kingship in a single place, and continuing use. AKL is emphatically about Assyrian kingship; it is not about the transfer of kingship from city to city and dynasty to dynasty, as is the Sumerian King List. ${ }^{19}$ Unlike other king lists, and as discussed

17 As noted in Yamada (1994: 11), "some of the problems involved in AKL must be related to the editorial history of the AKL.” Similarly, Wu (1990: 34) observes that "AKL is a compilation of the contemporary knowledge of the scribes and ancient tablets available to them, which must have included eponym lists, king lists, and inscriptions."

18 There is a long tradition of scholarship identifying this historical moment with the eighteenth century reign of Šamšì-Adad I. See, for example, Landsberger (1954: 109-10), Yamada (1994: 19), and, perhaps most explicitly, Grayson (1980-83: 102): “originally [AKL] seems to have been an attempt to prove that Šamši-Adad I was a legitimate ruler of the city-state Aššur and to obscure his non-Assyrian antecedents by incorporating his ancestors into a native Assyrian genealogy.” These views rest on the notion that Šamši-Adad had a particular interest in legitimating his rule in Aššur, which our knowledge of Aššur's place in his kingdom indicates he did not - see for instance Hallo (1978: 5-6), Charpin (2004b), and the balance of relations between Šamši-Adad and the Assyrians that is reflected in the letter from Assyrians to the ruler of Harsamna published in Günbattı (2014) (Kt 01/k 217). There is, more importantly, and as discussed at greater length below, no smooth succession of kings in AKL that aligns with the historical record until significantly after the reign of ŠamšīAdad, suggesting a later primary compilation of the text in its standard form.

19 See Janssen (2016) for the view that AKL models its early alternation between Amorite and Assyrian sections on the Sumerian King List. This view does not account for the fact that AKL nowhere acknowledges a difference between its Amorite and Assyrian components along those lines, crafting them instead into a single (impossible) sequence that we would not be able to divide into Amorite and Assyrian without other historical knowledge. This sequence also does not meander between locations, being instead confined to Aššur. The Sumerian King List is, by contrast, explicit about the transfer of power from place to place and dynasty to dynasty - indeed, this is its leitmotif. 
above, AKL is also a transparently composite text. It unites distinct sets of rulers and weaves them together to present them as sequential links in a single chain.

AKL's sections are reimagined as a coherent record of Assyrian rulership. Its first two sections are, for instance, placed in consecutive order by the duplication of the seventeenth entry in AKL, Apiašal. He features once at the end of AKL's first section and again at the chronological beginning of its second section. By duplicating Apiašal, AKL dispenses with any ambiguity about the sequential relationship that it is imposing on the two dissimilar sections in which he appears. Editorial intervention is still more stark in the transition between AKL's first two sections and its third section. The first two sections derive from Amorite genealogical traditions that are extrinsic to Assyrian history, ${ }^{20}$ whereas the third section consists of six historical Assyrian rulers. ${ }^{21}$ In the third section, only the first entry, Sulili, is given a filiation. As an irregularity, this is exceptional: all other entries in AKL comply with the basic format of the section in which they appear. The absence of filiations for five of the six entries of AKL's third section therefore implies that the insertion of a filiation for the first entry was a conscious editorial decision. Not only is the insertion of the filiation deliberate, but it is also historically untenable. ${ }^{22}$ Sulili is presented as the son of Aminu, who is chronologically the last entry in AKL's second section. Yet the historical Aminu was a contemporary of Šamšì-Adad (to whom AKL assigns the same father, Ila-kabkabu), ${ }^{23}$ who lived about two centuries after Sulili. Aminu can therefore not be Sulili's father. ${ }^{24}$ The introduction of this impossible filiation grafts the Amorite sections of AKL to the rest of the text, establishing a direct genealogical relationship between the last of the Amorite kings and the first entry in the roster of actual Assyrian rulers. This is instructive:

20 Argued expansively in Finkelstein (1966). Note also Benno Landsberger's caustic observation concerning the plausibility of the connection between the Amorite and Assyrian components of AKL: "dass eine Reihe von 9 assyrischen Königen, endend mehr als ein halbes Jahrhundert vor Puzur-Aššur I, ostkanaanäische Namen von reinstem Wasser getragen haben sollten, deren vorletzter 'zufällig' mit dem des vaters des Šamši-Adad I. gleichlautet, ist unvorstellbar,” for which see Landsberger (1954: 33).

21 Their historicity is discussed most recently in Veenhof (2017: 59). The last two of these rulers, Šalim-ahum and Ilu-šumma, are attested in Old Assyrian inscriptions from Aššur (see A.0.31 and A.0.32 in Grayson 1987); the first of these rulers is Sulili, who should perhaps be identified with the inscriptionally attested Șilulu (see A.0.27 in Grayson 1987).

22 The impossibility of Sulili's filiation has been noted by many scholars, including Van Seters (1983: 74), Yamada (1994: 19), and Veenhof (2017: 59).

23 For the complicated relationship between the historical Ila-kabkabu, Aminum, and ŠamšīAdad, see Birot (1985: 221-224) and Garelli (1985).

24 Incidentally, if the identification of Sulili with the Șilulu of A.0.27 in Grayson (1987) is correct, then this is still more evidence that Sulili was not the son of Aminu, since the Silulu inscription records that Dakiki was his father. 
AKL engineers a clear fiction to create the illusion of genealogical continuity between its disparate components.

A subtler editorial concern with continuity is evident in AKL's omission of several historical rulers from the eighteenth and possibly the seventeenth centuries BCE. Following the death of Išme-Dagan I - AKL's 40th entry - AKL neglects to include a number of rulers who are documented in other sources. In KAV 14, a fragmentary representative of a variant king list tradition, ${ }^{25}$ two rulers are recorded who are absent from AKL; the first of these is attested in contemporary evidence. ${ }^{26}$ Similarly, there is a surviving eighteenth century inscription from an Assyrian ruler named Puzur-Sîn, ${ }^{27}$ who is not listed in AKL or referred to in other surviving evidence. This inscription also refers to a ruler by the name of Asīnum, ${ }^{28}$ whom Puzur-Sîn claims to have deposed, and who is again absent from AKL. As these sources indicate, and as is corroborated by other evidence, the eighteenth century was a time of considerable political turmoil in Aššur and its environs. Although AKL acknowledges that the Assyrian throne was for some of this time occupied sequentially by seven named individuals whom it labels "sons of nobodies", 29 the sequence of rulers is nevertheless orderly and maintains the impression of institutional continuity, with kings succeeding one another in turn regardless of their fitness for the throne. ${ }^{30}$ This impression is bolstered by the omission of select rulers, which allows AKL to elide the messiness of a historical record of protracted turbulence and discontinuity. ${ }^{31}$ If AKL were our only source, its tidy sequence of kings would betray little trace of the

25 Edited in Grayson (1980-83: 115); see Schroeder (1920: 24) for a copy of the fragment. To the extent that it survives, KAV 14 also differs from AKL in its exclusive listing of the names of rulers; it omits both filiation and regnal length. For a recent discussion of the known variant Assyrian king list traditions, see Yamada (2017: 109-113).

26 These kings are Mut-asqur and Rīm[uš?]; Mut-Asqur is attested in correspondence from Mari as the son of Išme-Dagan I and thus as the grandson of Šamši-Adad I. See in particular ARM 26: 411 and 428 and ARM 28: 171.

27 A.0.40.1001 in Grayson (1987: 77-78).

28 Reade (2001: 6) (citing Irving Finkel) argues that the name Asinum could represent a derogatory moniker derived from the term assinnu; the person referred to as Asinum in the Puzur-Sîn inscription might thus represent someone else, perhaps Mut-Asqur.

29 Entries 41-47, none of whom is attested in other contemporary evidence.

30 Indeed, by AKL's reckoning all Assyrian kings who followed the six sons of nobodies are, in fact, descendants of the last of these, namely Adasi. To the extent that they were sons of nobodies, then, this genealogical origin was clearly not disqualifying for all the Assyrian rulers who succeeded them.

31 As discussed in Yamada (2017) and Lion (2011). Lion (2011: 153-154) argues that AKL deliberately elides Mittanian domination of Assyria from its record. 
momentous transition from the Old Assyrian system of government to Aššur's incorporation in the Upper Mesopotamian kingdom of Šamšì-Adad I, of the subsequent conflicts over control of Aššur, and of Aššur's later domination by foreign powers, first Babylon and then Mittani. For all that there were usurpers and instances of improper succession, in the telling of AKL the Assyrian king sequence remained unbroken.

AKL is not merely edited selectively to convey its message of continuity. The very language it uses reinterprets history through the lens of the permanence and unchanging nature of kingship. AKL's first prose passage, which follows the conclusion of its first group of seventeen entries, uses the standard logogram LUGAL (šarru) to describe the relevant individuals explicitly as kings. ${ }^{32}$ This is also true for the prose passages that pertain to the next two discrete groups of entries, while the remainder of AKL's entries are all said to "exercise kingship” (šarrūta ìpuš). AKL is thus unequivocal about its classification of each and every one of its entries as kings. While such overt and repeated classification is not standard among ancient Near Eastern king lists, it is especially remarkable in light of Assyrian history. Inscriptions survive for most Assyrian rulers from the third millennium through to the fall of Nineveh in 612 BCE, yet before the fourteenth century only one of these rulers refers to himself with the title of king. This individual is, moreover, none other than ŠamšīAdad I, whose title derived not from his rule over Aššur but rather from his much more extensive possessions throughout Upper Mesopotamia. ${ }^{33}$ Šamšì-Adad I is the exception that proves the rule: no Assyrian ruler adopts the royal title until the second half of the second millennium. ${ }^{34}$ This choice is not simply one of inherited

32 They are described as šarrāni (kings), written logographically and with a phonetic complement as LUGAL ${ }^{\text {meš } a-n i}$.

33 Eidem (2014: 137-138) offes a succinct account of the extraneousness of Šamšī-Adad's kingship to the Assyrian tradition; Eidem (2014) also makes the case that the natural heir to Šamši-Adad's confederate kingdom was not the Middle Assyrian polity, but rather Mittani.

34 The language of kingship does surface on two occasions. Copies of two inscriptions of the twentieth century Assyrian ruler Erišum I survive together in two tablets found in Kanesh (Kt a/ k 353 and Kt a/k 315, edited in Landsberger and Balkan 1950; as A.0.33.1 in Grayson 1987). In A.0.33.1: 20, there is a reference to šarrum šumšu ša kima yāti bētam eppaš (any king who like myself (re)builds the temple). Although this might imply that Erišum was in fact a king, the scrupulous avoidance of the title elsewhere and what we know of the actual position of Old Assyrian rulers (for which see Valk 2018: 116-124) suggests instead that the term here is simply intended as a generalized label for rulers rather than a claim to kingship. This reading is reinforced by a direct parallel to this passage in an actual inscription from the Aššur temple in Aššur (Grayson 1987: A.0.33.10: iii 4-5), in which Erišum uses the same set phrase but with the known Old Assyrian title rubā'um instead of the word 'king': rubā'um šumšu ša kima yāti (any ruler who is like myself). It is noteworthy that the word šarrum appears only in the copies of Erišum's inscriptions from Kanesh, but is absent in the actual inscription from Aššur. The 
practice. As the parallel and contemporary example of Ešnunna indicates, the royal title was significant. The rulers of Ešnunna had traditionally styled themselves in the same way as those of Aššur - they made use of the formula ÉNSI Ešnunna, analogous to the Old Assyrian title ÉNSI Aššur. Only when their ambitions and power swelled in the 19th century did they arrogate the royal title and begin to call themselves kings. ${ }^{35}$ Clearly, the title had meaning, and its absence in Assyrian rulership is important. AKL's use of the language of kingship to refer to 71 of its first 72 entries is, accordingly, plainly anachronistic. It serves to project backwards in time the idea that Assyria is an ancient kingdom, in which the institution of kingship - undifferentiated, constant, unchanging - is the permanent and defining fixture.

AKL tells a story. It invents a genealogical fiction to weave together its disparate parts, it dispenses with the complexities of Assyria's political history in favor of a smooth progression of kings, and it manufactures a narrative of Assyrian history that is inextricably dependent on the institution of kingship, which it imagines to be coeval with Aššur as a polity. AKL represents a concerted effort not only to tell a story of continuity, but to assert it in the face of discordant sources and much more complicated historical realities. This is a deliberate agenda that cannot simply be dismissed as a byproduct of the conventions of the king list genre.

\section{The compositional context}

How, then, are we to situate AKL historically? Scholars have sought to locate AKL's genesis in various different historical milieus. Building on a long interpretative tradition, A. K. Grayson and Shigeo Yamada argue for the composition of an incipient AKL under Šamšî-Adad I in the eighteenth century BCE ${ }^{36}$; Wu Yuhong

most generous interpretation is that Erišum's station is presented as the equivalent of that of the kings of other polities, but he is certainly not himself a king. The same interpretation should be extended to a comparable usage of the term šarrum in the inscription of Puzur-Sîn (A.0.40.1001: 34 in Grayson 1987), which is in any case influenced directly by the example of Šamšī-Adad.

35 Starting with Ipiq-Adad II, for whose inscriptions see Frayne (1990: E.4.5.14). For an overview of the reign of Ipiq-Adad II, see Charpin (2004a: 129-131).

36 Grayson (1980-83: 102) and Yamada (1994: 36 and passim) respectively; on this interpretative tradition see footnote 18 above. Their position is not inconsistent with Yamada's concept of editorial stages in the history of the AKL, but there is no continuity between any text produced under Šamšì-Adad or his immediate successors and the text that is produced in the Middle Assyrian period. As such, I would not speak of stages in the development of the AKL, but of the use of older sources - including perhaps the text hypothesized by Yamada - to create the AKL as we know it in a single moment. This agrees with $\mathrm{Wu}$ (1990: 34). 
and Beate Pongratz-Leisten suggest a Middle Assyrian origin ${ }^{37}$; and Joseph Azize has, by contrast, proposed a date as late as the eleventh century reign of Aššurnasirpal I. ${ }^{38}$ This is an incredible temporal range, spanning roughly seven centuries. Fortunately, it is possible to narrow this range significantly. A text published by Lambert in 1976 demonstrates beyond a reasonable doubt that AKL was known to a scholar working for Tukultī-Ninurta I in the thirteenth century, thereby establishing a secure terminus ante quem for AKL's composition. ${ }^{39}$ It is also possible to establish a terminus post quem. Whatever the prehistory of AKL and the sources upon which it draws, the text as it is known to us includes a number of historical, linguistic, and institutional features that place it in the Middle-Assyrian period at the earliest. Historically, AKL's king sequence does not align with Assyria's actual king sequence until the end of the seventeenth century BCE, suggesting an imperfect knowledge of the past (and thus the freedom to manipulate this past without offending contemporary sensibilities) that places the composition of AKL at some remove from this time. ${ }^{40}$ Linguistically, AKL uses the Middle Babylonian and Middle Assyrian term Karduniaš to refer to Babylonia, it lacks mimation, and it manifests the sound shift from št to lt in the word for tent, "kultāri" rather than "kuštāri". ${ }^{41}$ Institutionally, AKL refers throughout to kings, which is, as I have noted, entirely anachronistic given the adoption of the title by Assyrian rulers only in the fourteenth century. The temporal range for the composition of AKL is therefore much more modest than that suggested by modern scholarship - roughly three centuries between 1500 and 1200 BCE.

Within this timespan, the fourteenth century reign of AKL's 73rd entry - Aššuruballit I - constitutes an extraordinarily appropriate setting for the composition of AKL. ${ }^{42}$ Aššur-uballit’ 36 years on the Assyrian throne are a transformative period in Assyrian history. ${ }^{43}$ Politically, Aššur-uballit redefines his position. He is the first Assyrian ruler to style himself king, which he does both in his surviving correspondence with Egyptian pharaohs and in his seal. ${ }^{44}$ Because no correspondence or seals survive for any Assyrian rulers in the two centuries preceding Aššur-

$37 \mathrm{Wu}$ (1990) and Pongratz-Leisten (2015: 135-141) respectively.

38 Azize (1998).

39 BM 98496, edited and discussed in Lambert (1976).

40 It is largely for these same reasons that Galter (2002-05: 18) concludes that AKL could not have been composed before the sixteenth century reign of Šu-Ninua.

41 All three of these linguistic features are observed by Yamada (1994: 20-21), with references. 42 This setting is also suggested by Pongratz-Leisten (2015: 139), discussed in footnote 62 below.

43 For a reconstructed chronology of Aššur-uballiț’s reign, see Maidman (2011: 115-126).

44 Aššur-uballiṭ I styles himself king in Amarna letters 15 (Artzi 1978) and 16 (Artzi 1997) and in his seal (A.0.73.6 in Grayson 1987: 114-115), which survives in numerous impressions. 
uballit, it is possible to argue that his adoption of the royal title in these textual genres is not new, but simply not previously attested. This reading can also draw support from the fact that Aššur-uballit does not style himself king in his surviving inscriptions. ${ }^{45}$ As discussed above, however, the evidence from the first half of the second millennium suggests a scrupulous avoidance of the royal title. Similarly, in the example of the adoption of the royal title by the rulers of Ešnunna the change in titulature reflects a genuine change in their political situation and ambitions. The only comparable period of significant change in the political position and ambitions of the rulers of Aššur is the reign of Aššur-uballit. Maynard Maidman argues that Mittani dominated Aššur at least until the early years of Aššur-uballit’’s reign. This would make Aššur-uballit the liberator of Aššur, the remover of the yoke of foreign domination, and all the better suited to the initial adoption of the royal title. ${ }^{46}$ Such a view also comports with the broad evidence of reinvention during Aššur-uballit’’s reign. In the area of titulature as in much else, we should look to Aššur-uballit as a source of transformative change. Indeed, within a generation of Aššur-uballit the royal title penetrates the genre of royal inscriptions, too: from his grandson Arik-dīn-ili onward, Assyrian rulers style themselves explicitly as kings in their inscriptions, and most of Arik-dinn-ili's own inscriptions retroject this title to his own father and grandfather despite the absence of the title from their inscriptions. ${ }^{47}$ Interestingly, Arik-din-ili also retrojects the royal title to his great-grandfather Erība-Adad, ${ }^{48}$ who never claimed it himself and isn't referred to by that title in the inscriptions of his son and grandson. This is a glimpse of the reimagining of the Assyrian past at work, within only a few generations.

Aššur-uballit not only adopts the royal title, but does so in relation to māt Aššur - the land of Aššur - rather than in relation to the city or the god. ${ }^{49}$ This innovation is the earliest known expression of an Assyrian political identity that is conceived in territorial terms. ${ }^{50}$ The new royal title and its implicit claim to territorial control are indicative of an effort to refashion Assyria in the mould of

45 An innovation in titulature need not penetrate all genres simultaneously. In the Middle Assyrian Palace decrees (for which see Roth 1997: 195-209), for instance, all Assyrian rulers until Aššur-rēša-išši (1132-1115) BCE are identified by the title $u k l u$ (overseer); from Aššur-rēšaišši onward, they are all šar māt Aššur (king of the land of Aššur). This is despite the fact that by the reign of Aššur-rēša-išši AKL was already in existence and Assyrian rulers had identified themselves as kings across multiple genres for well over a century.

46 Maidman (2011: 104).

47 See his inscriptions under A.0.75 in Grayson (1987: 120-127).

48 A.0.75.1: 46-47 in Grayson (1987: 121).

49 The momentousness of this shift has been commented upon by many scholars, most recently Liverani (2017: 114).

50 On the implications of this change, see Cancik-Kirschbaum (2011: 74-75). 
the great powers of the late Bronze Age, which were similarly organized on the basis of king and country. ${ }^{51}$ Aššur-uballiț's aspiration to join the club of great powers is apparent in his surviving correspondence with the Pharaoh. In Amarna letter EA 16, Aššur-uballit addresses his Egyptian counterpart as his "brother" 52 - a bold claim to political parity according to the diplomatic conventions of the day, ${ }^{53}$ and all the more remarkable given Assyria's recent history of subjection to more powerful neighbors. ${ }^{54}$ The magnitude of this change is highlighted by EA 15, an earlier letter from Aššur-uballit to the king of Egypt, ${ }^{55}$ in which he does not yet use the language of brotherhood - though he also avoids the language of diplomatic inferiority - and states that none of his predecessors had corresponded with the Egyptian court. ${ }^{56}$ Within a single reign, Assyria went from having no direct contact with Egypt to claiming equal status.

Aššur-uballiț’s assertion of great power status is further reflected in the historical record. To the south, Aššur-uballit intervened militarily in Babylonia and installed a king of his choosing ${ }^{57}$; to the east, it was under Aššur-uballit that the kingdom of Arrapha was incorporated into Assyria ${ }^{58}$; to the west, Mittani's influence over Assyria was brought to a definitive end ${ }^{59}$; to the north, Assyria expanded toward the mountains. ${ }^{60}$ It is not without reason that Aššur-uballiṭ’s great-grandson Adad-nārārī I describes him as the "strong king, whose priesthood was outstanding in awesome Ekur and the well-being of his sovereignty was established as far away as the mountains, subduer of the land Mușru, disperser of the hordes of the extensive land of the Šubaru,

51 See Valk (2018: 195-200) for a brief overview of the transformation of Aššur into Assyria that sets the Middle Assyrian period apart from the Old Assyrian period. Although it is true that the combination of king and country is also adopted by minor powers, in the Assyrian context it is clearly part of a reconstruction of the Assyrian polity on the model of its intended peers.

52 Artzi (1997: 321). Addressing the king of Egypt, EA 16: 3-4 reads as follows: umma Ǎšuruballiț šar Aššur šarru rabû ahūkāma (Thus speaks Aššur-uballiț, king of Aššur, great king, your brother).

53 For which see Liverani (2001: Chapter 20).

54 For which see Lion (2011) and Maidman (2011).

55 EA 15, edited in Artzi (1978: 27).

56 EA 15: 7-10 in Artzi (1978: 27): mār šiprīya altaprakku ana amārīka u mātka ana amāri adi anni ša abba'ūya lā išpurū (I have sent my envoy to you to see you and to see your land, which up to now my fathers had not sent).

57 As recorded in the Synchronistic History (i: 8-17) and in Chronicle P (i: 2-14), for which see Grayson (1975: 159) and Grayson (1975: 171-172) respectively.

58 Maidman (2011: 100).

59 Maidman (2011: 104).

60 As per the royal inscription of Adad-nārārī I cited in the following footnote. 
extender of borders and boundaries"61 - high praise, and far in excess of that accorded by Adad-nārārī to his own father and grandfather. Politically, Aššur-uballiț’s reign is an unmistakable transitional point: before him, Assyria was a polity centered on the city of Aššur with little influence beyond it, often in thrall to its more powerful neighbours; after him, Assyria was a territorial entity beholden to none of its neighbors and with increasingly justified great power pretentions.

There were further developments in Assyria itself. It is under Aššuruballit that the Babylonian master-scribe (țupšarru) Marduk-nādin-ahhēe took up residence in Aššur, where a Babylonian quarter emerged that boasted its own temple to Marduk. ${ }^{62}$ It is probably not a coincidence that this was also a time of considerable innovation in Assyrian textual production. Aššuruballit is the first Assyrian king to leave behind numerous inscriptions of substantial length, commemorating his extensive construction projects in Aššur according to the format that would be adopted and expanded by his successors. It is also to this time that the Middle Assyrian Palace Decrees trace their origins, ${ }^{63}$ while the Middle Assyrian cuneiform ductus likewise undergoes significant development in the fourteenth century. ${ }^{64}$ All of these changes are indicative of a comprehensive reform effort that was remarkably successful in building a new Assyria and defining the contours of its future.

So where does AKL fit in this context of radical transformation? The composition of AKL is consistent with the vigorous and innovative textual production of the period, it is consistent with the political emphasis on kingship, and it is consistent with a desire to establish an institutional pedigree fit for a polity claiming parity with the Great Powers. This pedigree is exemplified by one notable innovation in Aššur-uballiț's inscriptions that is not repeated by his successors, namely the presentation of the king's genealogy to the sixth generation. ${ }^{65}$ This is in marked contrast to all previous and subsequent royal inscriptions, which do not normally record genealogies beyond two or three generations; it signals a desire to emphasize both royal continuity and the antiquity of Assyrian kingship - precisely the themes

61 A.0.76.1: 27-32 in Grayson (1987: 132). The passage is prefaced by the statement that Adadnārārī is the descendent of Aššur-uballiț: [Adad-nārārī] liplippu ša Aššur-uballiț šarri danni ša šangûšu ina ekur rašbi šūturat $u$ šulum šarrūtišu ana rūqāte kīma šadî kunnu mušekniš māt muṣri museppih ellat māt šubarê rapalti murappiš mișri u kudurri.

62 Wiggermann (2008). See Pongratz-Leisten (2015: 139) for the view that Babylonian scholarship exercised an influence on certain features of the AKL, and for the possibility that it was Marduk-nādin-aḩhē himself who wrote the AKL.

63 Roth (1997: 196-197).

64 Postgate (2014: 57).

65 A.0.73: 1-12 in Grayson (1987: 109-110). 
that characterize AKL. ${ }^{66}$ Dating AKL to the reign of Aššur-uballit I is thus consistent with that king's own ideological interests as they emerge from his inscriptions, as well as with the transformative character of his reign and its penchant for reinvention. No other context recommends itself anywhere near as strongly as a setting in which to locate the origins of the Assyrian King List.

\section{Conclusion}

The French ethnographer Jean Pouillon inverted the adage "plus ça change, plus c'est la même chose" (the more things change, the more they are the same) to produce "plus c'est la même chose, plus ça change" (the more things are the same, the more they change). ${ }^{67}$ Pouillon's idea is that the more a claim to continuity is asserted, the more there is reason to believe that change is being concealed. In other words, it is precisely when things are most in flux that the strongest claims to continuity are advanced. AKL's story is one of timeless continuity, of an abiding record of Assyrian kingship; Aššur-uballiṭ’s reign is one of transformative change, in which Assyrian kingship first erupts onto the stage of history. "Plus c'est la même chose, plus ça change" indeed.

\section{References}

Artzi, Pinḥas. 1978. The Rise of the Middle-Assyrian Kingdom, according to el-Amarna Letters 15 \& 16. Pp. 25-41 in Bar-llan Studies in History, ed. P. Artzi. Ramat-Gan: Bar-Ilan University Press. ---. 1997. EA 16. Altorientalische Forschungen 24: 320-336.

Azize, Joseph. 1998. Who Was Responsible for the Assyrian King List? Abr-Nahrain 35: 1-27. Birot, Maurice. 1985. Les chroniques "assyriennes" de Mari. MARI 4: 219-242.

Brinkman, John A. 1973. Comments on the Nassouhi Kinglist and the Assyrian Kinglist Tradition. Orientalia Nova Series 42: 306-319.

Cancik-Kirschbaum, Eva. 2011. Ashur - The Making of an Imperial Capital in the fifteenth and fourteenth Century BC. Mesopotamia 46: 71-78.

Charpin, Dominique. 2004a. Histoire politique du Proche-Orient amorrite (2002-1595). Pp. 23480 in Mesopotamien. Die altbabylonische Zeit, by D. Charpin, D. O. Edzard and M. Stol. Fribourg and Gottingen: Vandenhoeck \& Ruprecht.

---. 2004b. Mari und die Assyrer. Pp. 371-382 in Politische, wirtschaftliche und kulturelle Entwicklung im Zeichen einer Jahrtausendwende, eds. J. -. W. Meyer and W. Sommerfeld. Saarbrücken: Saarbrücker Druckerei und Verlag.

66 AKL's genealogical preoccupation is discussed in Pongratz-Leisten (1997: 92-93).

67 Pouillon 1977. Pouillon's adage was popularized in Anglophone scholarship through its use by the noted anthropologist Marshall Sahlins in Sahlins (1981: 7). 
Eidem, Jesper. 2014. The Kingdom of Šamšī-Adad and Its Legacies. Pp. 137-146 in Constituent, Confederate, and Conquered Space in Upper Mesopotamia. The Emergence of the Mittani State, eds. E. Cancik-Kirschbaum, N. Brisch and J. Eidem. Berlin, Boston: De Gruyter. Finkelstein, Jacob J. 1966. The Genealogy of the Hammurapi Dynasty. Journal of Cuneiform Studies 20: 95-118.

Frayne, Douglas. 1990. Old Babylonian Period (2003-1595 BC). The Royal Inscriptions of Mesopotamia: Early Periods, Volume 4. Toronto: University of Toronto Press.

Galter, Hannes D. 2002-05. Textanalyse assyrischer Königsinschriften: Der Aufstand des PuzurSîn. State Archives of Assyria Bulletin 14: 1-22.

Garelli, Paul. 1985. Réflexions sur les listes royales assyriennes. Pp. 91-95 in Miscellanea Babylonica: Mélanges offerts a Maurice Birot, eds. J.-M. Durand and J.-R. Kupper. Paris: Éditions Recherches sur les Civilisations.

Gelb, Ignace J. 1954. Two Assyrian King Lists. Journal of Near Eastern Studies 13: 209-230 and pls. XIV-XVII.

Grayson, A. Kirk. 1969. Assyrian and Babylonian King Lists: Collations and Comments. Pp. 105118 in Lišān Mithurti: Wolfram Freiherr von Soden zum 19. VI. 1968 gewidmet von Schülern und Mitarbeitern, eds. M. Dietrich and W. Röllig. Kevelaer: Butzon \& Bercker.

---. 1975. Assyrian and Babylonian Chronicles. Locust Valley: J. J. Augustin.

---. 1980-83. Konigslisten und Chroniken. B. Akkadisch. Reallexikon der Assyriologie 6: 86135.

---. 1987. Assyrian Rulers of the Third and Second Millennia BC (to 1115 BC). Toronto,Buffalo, London: University of Toronto Press.

Günbattı, Cahit. 2014. Harsamna Kralı Hurmeli'ye Gönderilen Mektup ve Kaniš Kralları/The Letter Sent to Hurmeli King of Harsamna and the Kings of Kaniš. Ankara: Türk Tarih Kurumu.

Hagens, Graham. 2005. The Assyrian King List and Chronology: A Critique. Orientalia Nova Series 74: 23-41.

Hallo, William W. 1978. Assyrian Historiography Revisited. Eretz-Israel 14: 1-7.

Janssen, Thomas. 2016. Die USKL als Vorbild für den 'Grundstock' der AKL. Nouvelles Assyriologiques Brèves et Utilitaires 2016/2: 62-64.

Lambert, Wilfred G. 1976. Tukulti-Ninurta I and the Assyrian King List. Iraq 38: 85-94. Landsberger, Benno. 1954. Assyrische Königsliste und "Dunkles Zeitalter.”. Journal of Cuneiform Studies 8: 31-45.

Landsberger, Benno and Kemal Balkan. 1950. Asur Kıralı Irişum'un Kültepe'de 1948'de Bulunan Kitabesi /Die Inschrift des assyrischen Königs Irişum, Gefunden in Kültepe 1948. Belleten 14: $171-268$ and pls. xvi-xxvi.

Lion, Brigitte. 2011. Assur unter der Mittaniherrschaft. Pp. 149-167 in Assur - Gott, Stadt und Land, ed. J. Renger. Wiesbaden: Harrassowitz Verlag.

Liverani, M. 1993. Model and Actualization: The Kings of Akkad in the Historical Tradition.

Pp. 41-67 in Akkad, the First World Empire: Structure, Ideology, Traditions, ed. M. Liverani. Padua: Sargon srl.

Liverani, Mario. 2001. International Relations in the Ancient Near East, 1600-1100 B.C. New York: Palgrave.

---. 2017. Assyria: The Imperial Mission. Translated by Jonathan Valk and Andrea Trameri. Winona Lake: Eisenbrauns.

Machinist, Peter Bruce. 1982. Provincial Governance in Middle Assyria and Some New Texts from Yale. Assur 3/2: 65-100. 
Maidman, Maynard P. 2011. Nuzi, the Club of the Great Powers, and the Chronology of the Fourteenth Century. KASKAL 8: 77-139.

Millard, A. R. 1970. Fragments of Historical Texts from Nineveh: Middle Assyrian and Later Kings. Iraq 32: 167-176.

Nassouhi, Essad. 1927. Grande liste des rois d'Assyrie. Archiv für Orientforschung 4: 1-11 and pls. I-II.

Poebel, Arno. 1942a. The Assyrian King List from Khorsabad. Journal of Near Eastern Studies 1: 247-306.

---. 1942b. The Assyrian King List from Khorsabad (Continued). Journal of Near Eastern Studies 1: 460-492.

Pongratz-Leisten, Beate. 1997. Genealogien als Kulturtechnik zur Begründung des Herrschaftsanspruchs in Assyrien und Babylonien. State Archives of Assyria Bulletin 11: 75-108.

---. 2015. Religion and Ideology in Assyria. Berlin, Boston: De Gruyter.

Postgate, Nicholas. 2014. Bronze Age Bureaucracy: Writing and the Practice of Government in Assyria. New York: Cambridge University Press.

Pouillon, Jean. 1977. Plus c'est la même chose, plus ça change. Nouvelle Revue de Psychanalyse 15: 203-212.

Pruzsinszky, Regine. 2009. Mesopotamian Chronology of the 2nd Millennium B.C.: An Introduction to the Textual Evidence and Related Chronological Issues. Vienna: Austrian Academy of Sciences Press.

Reade, Julian. 2001. Assyrian King-Lists, the Royal Tombs of Ur, and Indus Origins. Journal of Near Eastern Studies 60/1: 1-29.

Roth, Martha T. 1997. Law Collections from Mesopotamia and Asia Minor, 2nd ed. Atlanta: Scholars Press.

Sahlins, Marshall D. 1981. Historical Metaphors and Mythical Realities: Structure in the Early History of the Sandwich Islands Kingdom. Ann Arbor: University of Michigan Press.

Schroeder, Otto. 1920. Keilschrifttexte aus Assur verschiedenen Inhalts. Leipzig: J. C. Hinrichs. Valk, Jonathan. 2018. Assyrian Collective Identity in the Second Millennium BCE: A Social Categories Approach. Unpublished Ph.D. Dissertation, New York University.

Van Seters, John. 1983. In Search of History: Historiography in the Ancient World and the Origins of Biblical History. New Haven: Yale University Press.

Veenhof, Klaas R. 2017. The Old Assyrian Period (twentieth-eighteenth Century BCE). Pp. 57-79 in A Companion to Assyria, ed. E. Frahm. Malden: Wiley Blackwell.

Wiggermann, Frans A.M. 2008. A Babylonian Scholar in Assur. Pp. 203-234 in Studies in Ancient near Eastern World View and Society Presented to Marten Stol, ed. R. J. Van Der Spek. Bethesda: CDL Press.

Worthington, Martin. 2012. Principles of Akkadian Textual Criticism. Boston/Berlin: De Gruyter. Wu, Yuhong. 1990. Did the Assyrian King List Attempt to Prove the Legitimacy of Šamši-Adad? Journal of Ancient Civilizations 5: 25-37.

Yamada, Shigeo. 1994. The Editorial History of the Assyrian King List. Zeitschrift für Assyriologie 84: $11-37$.

---. 1998. The Assyrian King List and the Murderer of Tukulti-Ninurta I. Nouvelles Assyriologiques Brèves et Utilitaires 1998/1: 26-27.

---. 2017. The Transition Period (seventeenth to fifteenth Century BCE). Pp. 108-116 in A Companion to Assyria, ed. E. Frahm. Chichester: John Wiley \& Sons. 